\title{
Bibliotherapy Sebagai Upaya Meningkatkan Keterampilan Interpersonal Remaja
}

\author{
Triana Rosalina Noor \\ Sekolah Tinggi Agama Islam (STAI) An Najah Indonesia Mandiri Sidoarjo
}

\begin{abstract}
Literature or books is one of media that used to obtain information, knowledge and self-development. In addition literature also can be used to improve self development, especially teenagers. It becaused some teenagers has not optimize on improving their selves. They still have lack of interpersonal skills that make them difficult to do good adaption in their social environment. Bibliotherapy or or reading therapy is one alternative in dealing with self-development problems. In this way teenagers are expected to develop a more positive sense of themselves, provide insights into a problem, stimulate discussion of problems, provide solutions to problems, communicate new values and attitudes, and discover meaning in life. The choosen process of literature literature based on what problem faced. The goal is the process of reading therapy in order improving teenagers interpersonal skills maximized. In addition, the application of bibliotherapy also consider the interests and learning styles that are owned by teenagers.Bibliotherapy is very effective therapy for improving understanding and adding insight into teenagers according to reading material. Through bibliotherapy, teenagers are expected to find insight over obstacles their selves develompment to improve better interpersonal skills.
\end{abstract}

Keywords: Bibliotherapy; Interpersonal Skills; Teenagers

\begin{abstract}
Abstrak
Literatur atau buku merupakan salah satu media yang digunakan untuk mendapatkan informasi, pengetahuan dan pengembangan diri. Selain itu literatur bisa juga digunakan sebagai sarana dalam pengembangan diri seseorang, khususnya remaja. Hal ini dikarenakan usaha yang dilakukan dalam pengembangan diri remaja tidak selalu mendapatkan hasil yang maksimal. Masih ada remaja yang kurang memiliki keterampilan interpersonal sehingga membuatnya menjadi kurang bisa beradaptasi dengan lingkungan.Bibliotherapy atau terapi membaca merupakan salah satu alternatif terapi dalam menangani masalah pengembangan diri remaja. Melalui cara ini remaja diharapkan bisa untuk mengembangkan rasa yang lebih positif pada diri mereka sendiri, memberikan wawasan terhadap suatu masalah, merangsang diskusi tentang masalah, memberikan solusi untuk masalah, mengkomunikasikan nilai-nilai dan sikap baru, dan menemukan makna dalam kehidupan. Pemilihan literatur disesuaikan dengan permasalahan yang dihadapi agar bisa lebih optimal. Selain itu penerapan bibliotherapy juga mempertimbangkan minat dan gaya belajar yang dimiliki oleh remaja tersebut. Bibliotherapy sangat efektif untuk meningkatkan pemahaman dan menambah wawasan remaja sesuai dengan bahan bacaan. Melalui bibliotherapy, remaja diharapkan bisa menemukan insight atas
\end{abstract}


kendala yang menghambat pengembangan dirinya sehingga mampu mengembangkan keterampilan interpersonal yang dimiliki lebih baik lagi

Kata kunci: Bibliotherapy; Keterampilan Interpersonal; Remaja

Di Indonesia permasalahan perilaku remaja yang menyimpang dari norma-norma dan nilai sangat menarik perhatian banyak orang. Para orang tua, para pendidik, tokoh agama, tokoh pemuda, tokoh masyarakat maupun pemerintah ikut urun rembuug dalam memberikan solusi penyelesaian. Hal ini dikarenakan perilaku remaja yang menyimpang tersebut sudah menjadi fenomena sosial yang tidak terbantahkan (Puspensos, 2020). Di sisi lain, remaja merupakan anggota lapisan masyarakat yang masih berusia muda dan memiliki kedudukan yang penting dalam masyarakat. Remaja penting untuk berpartisipasi dan mengembangkan potensinya melalui pengembangan kebutuhan dan hak-haknya (WHO, 2020). Hal ini dikarenakan remaja merupakan harapan orang tua, masyarakat dan bangsa sebagai penerus cita-cita perjuangan bangsa dan calon pemimpin di masa depan (Setiawan, 2015).

Remaja sekarang yang biasanya disebut sebagai remaja milenial sangat identik dengan berbagai kemudahan dalam mengakses berbagai informasi dari daerah manapun tanpa harus tatap muka berkat kecanggihan teknologi gadget yang dimilikinya. Namun di balik kecanggihan teknologi dan kemudahan akses segala informasi membawa dampak buruk pada kehidupan sosial remaja itu sendiri. Remaja dapat dengan mudah mengakses informasiinformasi negatif dari manapun tanpa proses seleksi terlebih dahulu oleh karena besarnya rasa keingintahuannya atas hal baru (Fadillah, 2020). Bahkan sebagian besar kasus kenakalan remaja seperti tawuran dan perkelahian yang terjadi di Surabaya dikarenakan oleh informasiinformasi negatif yang didapatkan melalui informasi dari media sosial (Kompas, 2019). Generasi muda pada zaman pasca reformasi cenderung memilih sikap apatis dan tidak melakukan apa-apa bahkan lebih banyak sibuk dengan urusannya pribadi daripada ikut andil di lingkungan sekelilingnya (Noor, 2018a).

Tidak mengherankan masalah perilaku remaja ini menjadi perhatian serius dari semua pihak karena permasalahan tersebut telah menjadi salah satu masalah nasional yang perlu 
penanganan serius, menyeluruh dan terpadu dengan mengikutsertakan seluruh lapisan masyarakat.

Pada dasarnya semua manusia diciptakan dengan potensi dan pembawaannya masingmasing (Tafsir, 2014) yang dalam proses perkembangannya dipengaruhi oleh lingkungan dan pada nantinya akan menjadi sebuah keseimbangan tersendiri pada diri manusia tersebut (Noor, 2017a). Kondisi tersebut juga terjadi pada remaja, yakni pada dasarnya remaja tersebut memiliki potensi-potensi yang positif dan konstruktif yang akan berguna bagi dirinya ataupun masyarakat. Hal ini dikarenakan seorang remaja memiliki tugas perkembangan untuk menguasai kemampuan kontrol diri yang baik dan diharapkan sudah bisa memenuhi keinginan-keinginan dari lingkungan sekitarnya melalui sikap yang ditunjukkannya (Noor, 2019c). Remaja melalui potensi dan penalaran yang dimiliki secara umum sudah bisa membuat pertimbangan-pertimbangan dan melakukan perdebatan terkait hal normaif, keadilan ataupun topik-topik abstrak lainnya (Desmita, 2015), dan hal tersebut merupakan perkembangan yang cukup signifikan dibanding tahap perkembangan sebelumnya yakni anak-anak (Noor, 2017d).

Pada periode remaja adalah suatu periode yang tidak jelas pembedaannya dan terdapat keraguan atas peran yang harus dilakukan. Pada masa tersebut remaja bukan lagi seorang anak dan juga bukan orang dewasa (Hurlock, 2012). Masa remaja tidak mungkin terlepas dari permasalahan antara lain: masalah akademik, masalah dengan orang tua, masalah dengan guru, masalah dengan teman sebaya dan masalah dengan lingkungannya yang lain. Remaja dituntut mampu menyelesaikan masalah tersebut dengan tepat dan efektif melalui berbagai cara, namun tidak semua remaja mampu menyelesaikan masalahnya dengan baik dan memperoleh pemecahan masalah yang tepat. Hal ini bisa disebabkan oleh remaja tersebut masih membutuhkan waktu untuk menyesuaikan diri dengan peran barunya di lingkungan (Desmita, 2014). Bagi remaja yang memiliki penyesuaian diri yang buruk akan mengalami perasaan tidak bahagia (Hurlock, 2012).

Permasalahan remaja yang pada akhirnya menjurus kepada kenakalan remaja salah satunya disebabkan oleh kurangnya keterampilan interpersonal yang dimiliki oleh remaja itu sendiri. Keterampilan interpersonal remaja yang rendah akan selaras dengan permasalahan sosial yang dialami oleh remaja (Hendrik \& Elmansyah, 2018). Hal ini ditunjukkan adanya 
kesalahpahaman atau proses komunikasi yang kurang baik, kurang bisa menjalin hubungan sosial antara orang tua dan anak sehingga relasi yang terjalin bersifat negatif (Sari, 2019). Selain itu remaja milenial sekarang lebih banyak interaksi dengan gadgetnya sehingga membuat mereka seolah hidup pada "dunianya sendiri" (Astuti \& Rps, 2018).

Keterampilan interpersonal itu sendiri merupakan total dari kemampuan seseorang untuk menjalin interaksi secara efektif dengan orang lain (Johnson, 2014). Keterampilan interpersonal merupakan gabungan dari berbagai kemampuan yang bersifat soft skill dan noncognitive yang digunakan seseorang dalam berinteraksi dalam sosialnya (Bok, 2020). Johnson sendiri secara secara garis besar menjabarkan keterampilan interpersonal menjadi lima dimensi yaitu keterbukaan diri, kepercayaan, komunikasi, kemampuan mendengarkan dan penyelesaian konflik interpersonal (Johnson, 2014).

Sebuah hubungan sosial akan berjalan efektif manakala seseorang memiliki keterampilan interpersonal yang baik seperti komunikasi interpersonal yang memadai (Noor, 2019a). Jika seorang remaja memiliki keterampilan interpersonal yang baik akan memberikan manfaat tersendiri baginya dalam menjalani aktivitas kesehariannya. Remaja yang memiliki keterampilan interpersonal yang baik akan memiliki pemahaman baru terhadap diri dan lingkungannya (Fitriani \& Hidayah, 2016). Melalui keterampilan interpersonal akan mendorong timbulnya saling pengertian, saling menghargai dan saling mengembangkan hubungan interpersonal yang berkualitas (Rakhmat, 2013).

Suatu keterampilan yang dimiliki manusia tidak serta merta langsung dikuasai sejak lahir, namun membutuhkan proses dalam pembentukannya serta melibatkan pengalaman aktif dalam penerapannya (Noor, 2017c). Keterampilan interpersonal yang dimiliki oleh seseorang dapat dikembangkan pada sedini mungkin agar bisa lebih optimal. Hal ini dikarenakan semakin bertambahnya usia seseorang maka akan bertambah kompleks pulalah kebutuhan yang harus dipenuhinya kelak (Noor, 2017b). Artinya seseorang akan terpacu untuk bertindak atau berperilaku untuk memenuhi kebutuhannya agar bisa berkembang dan berinteraksi dengan orang lain dengan baik (Walgito, 2010), terlebih pada usia remaja yang seiring dengan perkembangannya memiliki salah satu tugas perkembangan yakni mengembangkan perilaku sosial yang bertanggung jawab (LN \& Nurihsan, 2007). Remaja memiliki kebutuhan dasar yang 
meningkat daripada saat masa kanak-kanak terlebih terkait dalam hal mencari pengalaman baru dan pengakuan dari lingkungan sosialnya (Hamalik, 2010).

Salah satu alat yang dapat digunakan untuk mengembangkan keterampilan interpersonal adalah bibliotherapy, karena pada intinya bibliotherapy merupakan salah satu terapi yang manjur dalam penanganan gangguan psikologis tujuan untuk membantu individu dalam proses penyesuaian diri (Shechtman, 2009).

Bibliotherapy merupakan sebuah aktivitas yang diawasi dan terencana yang membantu pembacanya mendapatkan insight healing dari bukunya dibacanya (Doll \& Doll, 1997). Bibliotherapy adalah salah satu bentuk terapi dengan menggunakan literatur merupakan salah satu alat yang dapat digunakan untuk membantu memperlancar proses penyembuhan, adaptasi, atau pertumbuhan seseorang (Nugent, 2002). Bibliotherapy menggunakan buku yang baik sebagai upaya dalam melakukan healing psikologis seseorang. Pembaca akan dikondisikan untuk mengekspresikan tiap lembar buku yang dibacanya sebagaimana menonton hal visual yang bisa merasakan karakter yang ada didalamnya (Shechtman, 2009).

Aktivitas membaca dalam bibliotherapy akan menggunakan buku yang sesuai dengan usia pembaca untuk kemudian akan dilanjutkan dengan diskusi sesuai dengan topik masalah pengembangan diri yang ingin ditingkatkan. Bibliotherapy digunakan oleh konselor sekolah, pekerja sosial, perawat kesehatan, guru dan pustakawan. Penggunaan buku sebagai terapi untuk mendukung kebutuhan anak dalam memproses informasi untuk meningkatkan pemahaman dan meningkatkan kesadaran dalam masalah yang dialami dan tidak terkecuali kepada remaja. Melalui terapi ini akan membawa pengaruh padasikap, perasaan, dan perilaku remaja sesuai dengan yang diharapkan (Syafwar, 2016).

Oleh karena itu, agar remaja pada nantinya bisa menjadi individu yang berhasil di perkembangan selanjutnya, maka remaja harus banyak belajar untuk dapat memperoleh tempat dalam masyarakat sebagai warga negara yang bertanggung jawab serta dapat menjadi generasi penerus bagi nusa, bangsa dan agama kelak. Hal tersebut bisa dicapai manakala 
remaja tersebut mengembangkan potensi-potensi yang ada di dalam dirinya dengan baik, sebagaimana relevan dengan tujuan pendidikan khususnya pendidikan Islam (Noor, 2019b).

\section{Metode}

Metode penelitian yang digunakan dalam penulisan artikel ilmiah ini adalah menggunakan penelitian kepustakaan. Peneliti menelaah teori-teori, konsep-konsep, definisi, pengertian tentang variabel-variabel yang diteliti untuk dicari keterkaitannya. Peneliti akan mencoba menghubung-kaitkan antara data-data, konsep-konsep yang ada, mana yang menjadi sebab dan dampak (Fatihudin, 2015). Data-data tersebut peneliti ambil bersumber dari buku, jurnal, dan artikel, ilmiah. Metode pembahasan yang digunakan adalah menggunakan metode deskriptif-analisis, yakni peneliti menjelaskan serta mengelaborasi ide-ide utama yang berkenaan dengan topik yang dibahas, untuk selanjutnya disajikan dalam bentuk narasi kritis dengan mengacu pada sumber pustaka primer dan sekunder.

\section{Pembahasan}

\section{Bibliotherapy Sebagai Salah Satu Upaya Pengembangan Diri}

Penerapan Bibliotherapy

Secara umum, bibliotherapy mengacu pada penggunaan literatur untuk membantu seseorang menyesuaikan diri dengan permasalahan emosional, gangguan mental, atau mengatasi perubahan dalam hidup (Pardeck, 1995). Bibliotherapy dapat menurunkan kecemasan sosial dan membawa dampak pada perkembangan kognitif dan afeksi pada anak dan dewasa (Betzalel \& Shechtman, 2010).

Ada beberapa poin yang secara implisit termasuk dalam definisi bibliotherapy (Hynes \& Hynes-Berry, 1986), yakni :

a. Bibliotherapy adalah proses yang interaktif

b. Literatur dapat didefinisikan secara luas (tidak terbatas hanya pada buku)

c. Prosesnya dapat dilakukan dalam bibliotherapy dengan setting klinis dan setting 
perkembangan umum serta pendidikan

d. Praktek bibliotherapy dapat dilakukan dalam setting individual maupun kelompok

e. Hasil dari bibliotherapy yang efektif adalah berkembangnya self-esteem dan asimilasi nilai-nilai sosial atau psikologis yang lebih adaptif ke dalam karakter maupun perilaku partisipan.

f. Bibliotherapy merupakan sebuah terapi, tetapi memiliki keunikan yaitu efektivitas terapi diperoleh dari penggunaan literatur sebagai alat utama. Bibliotherapy secara spesial menyehatkan aspek kognitif baik untuk partisipan klinis maupun perkembangan umum. Bibliotherapy interaktif lebih ditujukan untuk mendukung dan memberikan penguatan kepada participan daripada diagnosis area permasalahan.

g. Keefektifan bibliotherapy tergantung pada kemampuan fasilitator untuk memilih materi yang sesuai dengan kebutuhan dan minat partisipan, memberikan interpretasi yang akurat dan empatik terhadap respon partisipan membantu partisipan memahami diri sendiri dengan lebih mendalam melalui literatur dan dialog.

Literatur yang dimaksudkan dalam bibliotherapy tidak dibatasi hanya puisi atau tulisan-tulisan kreatif, tetapi dapat diterjemahkan secara luas. Puisi mungkin adalah bentuk yang paling umum digunakan tetapi materi bibliotherapy tidak harus bersifat imajinatif, materi yang sifatnya didaktik atau informasional juga bisa digunakan. Permainan, cerita pendek, esai, artikel majalah, bagian-bagian tertentu dari textbook dapat juga digunakan secara keseluruhan atau sebagian, kutipan-kutipan juga dapat dipakai sebagai materi (Hynes \& Hynes-Berry, 1986).

Kelebihan-kelebihan pennerapan bibliotherapy dibandingkan terapi yang lainnya (Hynes \& Hynes-Berry, 1986), yaitu :

a. Interaktif

b. Mampu menembus sikap defensif dan resisten

c. Mengembangkan kemampuan imajinasi

d. Mengembangkan kemampuan problem solving

e. Ada banyak kemungkinan akhir cerita yang bisa diciptakan 
f. Membentuk sikap mandiri dalam pengambilan keputusan

Bibliotherapy adalah salah satu bentuk terapi dengan menggunakan literatur yang dapat membantu memperlancar pemahaman, katarsis dan mempermudah penyelesaian masalah yang dihadapi seorang remaja, terlebih yang memiliki kaitan dengan interaksi dengan orang lain (Doll \& Doll, 1997). Dalam bibliotherapy terdapat sebuah proses interaksi dinamis antara seseorang dan literatur, yang mementingkan respon emosional pembaca tentang apa yang telah dibacanya (Shechtman, 2009).

Reynales memaparkan bahwa bibliotherapy membantu pengembangan pribadi dan adaptasi sosial. Bibliotherapy memampukan siswa untuk berhadapan dengan berbagai penyesuaian diri yang harus dilakukan dalam masa perkembangan usia remaja (Nugent, 2002).

Tujuan Bibliotherapy

Adapun tujuan yang hendak dicapai dalam penerapan bibliotherapy (Hynes \& HynesBerry, 1986), yakni :

a. Mengembangkan kapasitas untuk merespon dengan menstimulasi dan memperkaya bayangan dan konsep mental, dengan mengangkat gambaran-gambaran mental tersebut ke permukaan. Dalam mengembangkan kapasitas untuk merespon, beberapa hal yang dilakukan adalah mememberikan stimulasi mental atau imajinatif

b. Memberikan pengalaman kebebasan kepada partisipan untuk menikmati keindahan yang terkandung dalam materi (menciptakan keselarasan dan keutuhan diri)

c. Meningkatkan pemahaman diri dengan membantu individu meninjau keberadaan diri dan menjadi lebih berpengetahuan, juga lebih akurat dalam mempersepsikan diri sendiri. Peningkatan pemahaman diri dilakukan melalui peningkatan kemampuan memberikan afirmasi kepada diri sendiri dengan:

d. Meningkatkan kesadaran dalam relasi interpersonal

e. Mengembangkan orientasi realitas, Tujuan-tujuan di atas tidak harus dicapai berurutan, 
tetapi lebih bersifat komprehensif dan saling melengkapi. Keempat tujuan di atas mempunyai sebuah tujuan yang komprehensif, yaitu untuk mengembangkan self eteem dan moralitas partisipan

\section{Proses Bibliotherapy}

Pada setting kelas atau pendidikan, literatur lebih dipakai sebagai objek diskusi sedangkan dalam bibliotherapy, respon perasaan individual terhadap literatur lebih penting daripada perolehan pengetahuan secara intelektual saja. Jadi, dalam bibliotherapy, bahkan kesalahan interpretasi akan maksud teks dibenarkan saja terjadi dan tetap berguna apabila memungkinkan terjadinya ekspresi perasaan atau insight yang terkait dengan pemahaman diri. Pada proses bibliotherapy, literatur digunakan sebagai katalisator dengan harapan literatur tersebut akan mengundang respon yang menadlam dari tiap subyek. Pembaca bebas untuk merefleksikan bacaan pada area permasalahan pribadi atau untuk mendapatkan penguatan (Hynes \& Hynes-Berry, 1986).

\section{Tahapan dalam Bibliotherapy}

Adapun tahapan-tahapan yang haru dilakukan dalam penerapan bibliotherapy kepada masing-masing individu (Hynes \& Hynes-Berry, 1986) yakni :

a. Tahap recognition

Bibliotherapy diawali dengan tahap pengenalan atau pengakuan. Pada tahap awal ini, diharapkan ada 'sesuatu' dari literatur yang menarik, mengikat perhatian, dan mempengaruhi partisipan. Hal yang harus dimunculkan dari 'sesuatu' tersebut adalah pemahaman mengenai diri pribadi atau pemahaman akan pengalaman, lebih dari sekedar "ini hanya sebuah cuplikan film atau lembaran cerita.

Pada tahap ini, diharapkan partisipan menghadirkan diri dalam literatur yang ia baca itu. Tahap recognition ini sifatnya sangat individual. Tahap ini bisa berlangsung cepat dan bermakna sangat dalam bagi seseorang sedangkan bagi orang lain dapat berlangsung dengan lambat dan pada taraf yang lebih konkrit. 


\section{b. Tahap examination}

Pada tahap ini, partisipan berubah dari sekedar mengenali perasaan-perasaan menjadi memeriksa konsep-konsep atau perasaan-perasaan mengenai dirinya sendiri. Partisipan diajak untuk mengeksplorasi perasaan-perasaan dan respon- respon seperti apa yang biasa mereka munculkan. Tahap pemeriksaan ini melibatkan pertanyaanpertanyaan seperti, "who", "what", "when", "why", "how", "how much", dan "wherefore". Pertanyaan-pertanyaan ini memungkinkan partisipan memeriksa kembali apa perasaanperasaaan mereka yang sebenarnya, kapan perasaan-perasaan tersebut muncul, serta kebenaran mengenai motif-motif apa yang sebenarnya mendasari pikiran, perasaan, atau perilaku mereka.

c. Tahap juxtaposition

Setelah mengenali dan memeriksa pikiran atau perasaan yang muncul, tahap selanjutnya adalah juxtaposition, yaitu membandingkan dan mengkontraskan diri (respon yang biasa dimunculkan, karakter, gambaran diri, atau situasi) dengan apa yang ada dalam bacaan.

\section{d. Tahap application to self}

Bibliotherapy tidak dapat hanya berhenti pada tahap pembandingan diri. Segala perasaan dan konsep yang telah dikenali, diperiksa, dan dibandingkan, pada tahap ini harus dialami secara tulus. Partisipan menyelesaikan seluruh rangkaian proses dengan melakukan evaluasi dan integrasi bersama-sama.

Evaluasi dilakukan partisipan dengan melihat ke dalam diri agar menjadi lebih aware dengan diri mereka sendiri, mereka harus melihat bagaimana sikap dan perilaku dipengaruhi oleh sudut pandang yang baru. Bila pengalaman ini benar-benar bersifat terapeutik, partisipan harus berubah lebih dari sekedar kesadaran secara kognitif dan terlibat dalam komitmen untuk menggunakan sikap yang baru sebagai referensi untuk menentukan respon dan tindakan yang akan dilakukan. Dengan kata lain, insight yang diperoleh harus terintegrasi. Sebagai proses, bibliotherapy bersifat berkelanjutan, melibatkan proses analisis dan sintesis, bersifat kreatif, serta penggunaan bahasa sebagai kunci utama. 
Hal yang terutama harus ada dalam proses bibliotherapy dari tahap awal hingga akhir adalah adanya penguatan bagi individu (Hynes \& Hynes-Berry, 1986).

\section{Peran Bibliotherapy Dalam Meningkatkan Keterampilan Interpersonal Remaja}

Bibliotherapy atau terapi baca adalah suatu bentuk penanganan dengan menggunakan literatur seperti buku atau karya sastra untuk membantu seseorang dalam pengembangan dirinya. Dalam prakteknya, bibliotherapy telah diterapkan dalam setting individual maupun kelompok. Materi bibliotherapy adalah seperti “orang” asing yang mengajak partisipan untuk memasuki sebuah perjalanan pemahaman diri (Shechtman, 2009). Peran guru dalam bibliotherapy dapat dilihat sebagai orang lain yang membantu proses pencarian ini, demikian juga masih memungkinkan adanya "orang lain" yang lain lagi yang dapat berkontribusi dalam proses pertumbuhan ini. Orang lain inilah yang dimaksud dengan kelompok dalam interactive bibliotherapy.

Melalui bibliotherapy remaja mempunyai kesempatan untuk mengenali dan memahami dirinya sendiri, memahami karakteristik diri, serta kekompleksan pemikiran maupun perilaku manusia. Bibliotherapy juga mengakibatkan perkembangan sosial, seperti kesukaan akan literatur secara umum dan peningkatan minat baca secara khusus.Perasaan terisolasi yang mungkin dirasakan oleh individu-individu bermasalah juga dapat dikurangi dengan membaca literatur.

Kemampuan bibliotherapy untuk mengembangkan keterampilan interpersonal akan tercapai dan optimal manakala ditunjang oleh pemilihan materi bibliotherapy yang semakin sesuai dengan kondisi dan kebutuhan pembaca akan semakin meningkatkan kemungkinan pembaca untuk terlibat dan menjadikan tokoh dalam bacaan sebagai model. Hal ini disebabkan berubahnya orientasi seseorang atas suatu hal disebabkan adanya sebuah pengalaman pribadi dan model dari lingkungan (Noor, 2018b). Materi bacaan harus disesuai dengan kondisi pembaca. Literatur yang digunakan sesuai dengan keadaan yang dialami oleh pembaca. Kemampuan untuk memilih materi yang sesuai dengan kebutuhan 
dan minat partisipan ini merupakan salah satu faktor yang mendukung keefektifan bibliotherapy (Berry\&Hynes, 1994).

Melalui topik dan pemilihan tema literatur yang digunakan, harapannya bibliotherapy dapat membuat remaja meresapi dan terdorong secara afektif dan kognitif dalam memenuhi kebutuhan-kebutuhannya terkait keterampilan interpersonal. Keterampilan yang meliputi dalam hal keterbukaan diri, kepercayaan, komunikasi, kemampuan mendengarkan dan penyelesaian konflik interpersonal (Johnson, 2014).

\section{Aspek Keterbukaan diri}

Melalui bibliotherapy, diharapkan dapat meningkatkan kemampuan remaja untuk bisa lebih bersikap terbuka dengan orang lain. Remaja diharapkan mampu mengungkapkan kepada orang lain atas situasi yang dirasakan dan memberikan informasi tentang dirinya dan masa lalunya yang relevan dengan persepsi dan tingkah lakunya di masa sekarang (Johnson, 2014). Remaja terkadang memiliki kendala dalam berbagai lingkungan sosial sehingga membuatnya menjadi tertutup dan sulit membuka diri (Andayani, 2010). Kesulitan membuka diri pada remaja mungkin bisa disebabkan oleh beberapa hal (DeVito, 2013), yaitu :

a. Keterbukaan dari orang lain

Keterbukaan diri adalah suatu hubungan yang terjalin timbal balik. Seseorang akan membuka dirinya kepada orang lain manakala orang lain tersebut juga melakukan hal yang sama seperti apa yang dilakukan. Seseorang akan cenderung menyukai untuk bersikap terbuka pada hal yang sama dengan apa yang dirasakan oleh orang lain sehingga terjalin interaksi antara keduanya.

b. Jumlah dari lawan komunikasi

Seseorang akan bersikap terbuka tergantung pada kelompok yang dihadapi. Jika interaksinya dilakukan pada suatu kelompok kecil yang hanya terdiri dari dua, tiga orang maka ia cenderung bisa bersikap terbuka. Namun jika kelompok yang dihadapi tergolong kelompok yang besar, mungkin reaksi yang dimunculkan berbeda, yaitu dengan cara masih menyembunyikan sesuatu kepada lawan interaksinya.

c. Topik 
Topik bisa mempengaruhi seseorang untuk melakukan keterbukaan diri. Topik yang yang bersifat umum akan membantu seseorang untuk bersikap terbuka kepada orang lain, namun topik yang menyangkut hal yang sangat pribadi dan yang memiliki potensi mengancam diri akan cenderung dihindari sebagai topik pembicaraan.

d. Sifat dari keterbukaan diri

Sifat dari keterbukaan mempengaruhi seseorang untuk bersikap terbuka. Keterbukaan pada hal yang positif cenderung akan lebih disukai daripada keterbukaan yang bersifat negatif. Hal ini cukup terkait dengan kepercayaan, manakala keterbukaan seseorang kepada orang lain juga terkait dengan kepercayaan seseorang kepada orang lain tersebut.

e. Jenis kelamin

Berdasarkan banyak penelitian yang telah menyatakan kalau perempuan akan bersikap lebih terbuka daripada laki-laki. Laki-laki dalam berkomunikasi lebih bersifat agresif dan perempuan lebih hangat dan lebih akrab (Kuntjara, 2003).

f. Hubungan dengan lawan komunikasi

Kedekatan seseorang dengan lawan komunikasinya akan berpengaruh pada sikap terbukanya pada hal yang akan diungkapkan. Keterbukaan terkait pula dengan frekuensi pertemuan sehingga secara bertahap akan memunculkan sikap terbuka pada orang lain. dan remaja masih mengalami kesulitan dalam hal menjalin hubungan komunikasi dengan orang lain (Rahma \& Lestari, 2018).

Harapannya pemilihan literatur yang tepat pada bibliotherapy, seorang remaja akan lebih bisa mengungkapkan perasaan, informasi pribadi kepada orang lain. Hal ini dilakukan dengan harapan dapat terjalin hubungan yang efektif antara satu dengan yang lain. Selain itu juga bisa meningkatkan kesadaran diri dan memberikan klarifikasi atas pemahaman diri sendiri serta bisa menjadi suatu media diskusi atas hal yang selama ini menjadi stressor agar tercapai suatu solusi atas permasalahan yang dialami (Johnson, 2014).

\section{Aspek Kepercayaan}


Kepercayaan adalah suatu bentuk menggantungkan diri kepada orang lain dengan menyadari pada nantinya akan muncul konsekuensi positif dan negatif dari menggantungkan diri tersebut. Remaja yang memiliki ketidakmampuan dalam mengenali emosi akan sulit menjalin persahabatan dan memiliki kepercayaan pada orang lain (Rahmat, 2014). Kesulitan dalam memberikan kepercayaan kepada orang lain bisa disebabkan karena adanya respon penolakan, penghinaan atau tidak menghargai oleh lingkungan. Adanya perilaku tidak kooperatif dari remaja juga bisa menyebabkan sulitnya terjalin interaksi yang baik dengan lingkungan (Johnson, 2014).

Aspek Komunikasi Interpersonal

Komunikasi interpersonal adalah suatu perilaku yang ditunjukkan dalam bentuk verbal maupun nonverbal yang didapatkan dari orang lain, biasanya terkait dengan suatu pesan yang dikirim oleh pribadi satu dengan yang yang lain. Hubungan akan berjalan efektif manakala komunikasi interpersonal yang dilakukan juga efektif. Untuk mencapai suatu komunikasi interpersonal yang efektif bagi remaja bisa dimulai dengan cara mengungkapkan suatu hal melalui komunikasi verbal dan non verbal secara kongruen. Pada konteks ini, bibliotherapy yang diberikan kepada remaja akan berisi materi terkait pentingnya katarsis dan mengutarakan perasaan yang dimiliki kepada orang lain sehingga remaja memiliki keterampilan komunikasi yang baik (Hasfera, 2018). Remaja sebelumnya diajak untuk menyukai terlebih dahulu pentingnya sebuah komunikasi dibentuk anatar indovidu satu dengan yang lain melalui topik-topik yang disajikan melalui literatur yang digunakan. Hal ini dikarenakan jika salah satu merasa tidak senang dengan komunikasi yang dilakukan maka ia akan mengakhiri komunikasi tersebut dan tidak lagi ada pesan yang diberikan atas suatu hal dan hubungan akan berhenti dengan sedirinya (Rakhmat, 2013).

Aspek Mendengarkan

Nilai-nilai yang terkandung dalam literatur pada bibliotherapy pada nantiya akan membawa remaja untuk bisa memiliki empati, kerjasama dan saling menolong serta sikap prososial (Novita, Sugiharto, \& Anni, 2017). Sikap prososial dibutuhkan seiring dengan 
pertambahan usia agar pada nantinya remaja bisa semakin memahami atau menerima norma-norma sosial. Adapun faktor yang berpengaruh pada sikap prososial adalah adanya kejelasan stimulus yang diterima oleh indera dan mendengar merupakan salah satunya (Dayakisni \& Hudaniah, 2012). Artinya melalui bibliotherapy remaja diharapkan bisa merasakan dari orang yang melakukan komunikasi dengannya dalam sebuah interaksi sosial.

\section{Aspek Penyelesaian Konflik Interpersonal}

Bibliotherapy akan membawa seseorang pada sebuah pemahaman baru yang akan memberikan solusi penyelesaian atas masalah yang dialami. Melalui literatur yang dibaca, seseorang akan diajak untuk lebih memahami apa yang sebenarnya atas hal yang belum dikenali dalam dirinya. Bibliotherapy membawa seseorang apa sebuah transfer nilai dan sikap yang baru untuk selanjutnya membantu dalam menata kognitif untuk menyelesaikan permasalahan yang dialami baik itu dalam diirnya ataupun orang lain (Novita et al., 2017). Manakala seseorang mengalami ketidakselarasan, ketidaksependapatan ataupun pertentangan kepentingandengan orang lain maka konflik interpersonal akan mudah sekali terjadi (Dayakisni \& Hudaniah, 2012).

Ada beberapa nilai-nilai dari strategi penyelesaian konflik yang bisa dimasukkan dalam bacaan yang pada nantinya bisa dipilih sebagai solusi penyelesaian masalah. Adapun strategi dasar yang biasanya digunakan adalah menghindari masalah, strategi menekan, strageti mengalah, melakukan kompromi dan melakukan negosiasi dengan oran lain (Noor, 2020).

\section{Efektifitas Bibliotherapy Dalam Meningkatkan Keterampilan Interpersonal Remaja}

Bibliotherapy dengan segala kelebihannya juga memiliki keterbatasan dalam penerapannya. Keterbatasan tersebut terletak pada ketersediaan topik-topik materi tertentu, kurangnya kesiapan maupun kesediaan individu untuk konsisten dan disiplin membaca (Gladding \& Gladding, 1991). Padahal disiplin merupakan salah satu sikap yang bisa mendorong seseorang untuk melaksanakan tanggung jawab atas tugas yang diberikan kepadanya (Noor \& Astutik, 2019). 
Keterbatasan lainnya adalah motif-motif pribadi pada karakter dalam buku dan justru memperkuat solusi dan persepsi diri sendiri pembaca sehingga membawa dampak pada perkembangan pembacanya. Pembaca mungkin justru akan mungkin bertindak defensif atau bahkan mejadi selektif dalam menelaah perilaku tokoh dalam materi. Akibatnya adalah kegagalan untuk mengidentifikasikan diri sendiri dengan tokoh cerita yang ada pada literatur (Gladding \& Gladding, 1991). Pada konteks ini, proses aktif interaktif dua arah yakni dari fasilitator ke remaja bisa dilakuka sebagai usaha untuk memaparkan isi dari materi bacaan yang dibaca (Asrori, 2009).

Keterbatasan lainnya adalah proses pemilihan literatur yang sudah dilakukan, belum maksimal dalam pembahasan topiknya. Artinya intisari dari suatu literatur belum diungkap secara mendalam, hanya pada permukaanya saja. Hal ini menyebabkan penggalian sikap kritis kurang bisa didapatkan saat penerapan bibliotherapy. Dengan memberikan literatur yang relevan dengan situasi kehidupan individu, maka bibliotherapy dapat membantu untuk memahami diri sendiri dan menyesuaikan diri (Hussin, Ibrahim, \& Shafie, 2014).

\section{Kesimpulan}

Bibliotherapy atau terapi membaca bisa dijadikan sebagai alternatif dalam mengembangkan diri seorang remaja, khususnya terkait masalah kemampuan keterampilan interpersonal. Pada penerapannya, bibliotherapy bisa digunakan dalam mengembangkan keterampilan interpersonal remaja. Hal ini dikarenakan melalui bibliotherapy atau terapi membaca remaja akan diajak untuk menyelami isi bacaan, memahami inti dari bacaan sehingga mendapatkan insight yang akan membawa remaja tersebut dalam mahir melakukan keterampilan interpersonal.

Saran

Adapun hal yang perlu diperhatikan dalam penerapan bibliotherapy ini adalah pemilihan bahan bacaan yang harus disesuaikan dengan karakteristuk masalah pengembangan diri yang dialami remaja. Selain itu minat dan gaya belajar remaja juga 
menjadi pertimbangan dalam memutuskan literatr seperti apa yang bisa diberikan kepada remaja untuk dijadikan referensi.

\section{Referensi}

Andayani, T. R. (2010). Penyesuaian Sosial Siswa Akselerasi Ditinjau dari Konsep Diri dan Membuka Diri. Jurnal Pendidikan Dan Kebudayaan, 16(7), 13-20. https://doi.org/10.24832/jpnk.v16i7.503

Asrori, M. (2009). Psikologi Pembelajaran. Bandung: CV . Wacana Prima.

Astuti, A. P., \& Rps, A. Nu. (2018). Teknologi Komunikasi dan Perilaku Remaja. Jurnal Analisa Sosiologi, 3(1).

Betzalel, N., \& Shechtman, Z. (2010). Bibliotherapy Treatment for Children With Adjustment Difficulties: A Comparison of Affective and Cognitive Bibliotherapy. Journal of Creativity in Mental Health, 5(4), 426-439. https://doi.org/10.1080/15401383.2010.527816

Bok, D. (2020). Improving Interpersonal Skills. In Can Colleges Teach Students What They Need to Know in the 21st Century? Higher Expectations (pp. 95-108). https://doi.org/10.2307/j.ctv13vdhp1.10

Dayakisni, T., \& Hudaniah, H. (2012). Psikologi Sosial. Malang: UMM Press.

Desmita, D. (2014). Psikologi Perkembangan Peserta Didik. Bandung: PT.Remaja Rosdakarya.

Desmita, D. (2015). Psikologi Perkembangan. Bandung: PT. Remaja Rosdakarya.

DeVito, J. A. (2013). The Interpersonal Communication Book. USA: Pearson.

Doll, B., \& Doll, C. (1997). Bibliotherapy With Young People. USA: Libraries Unlimited.

Fadillah, G. F. (2020). Optimalisasi Peran Orang Tua Dalam Memahami Remaja Generasi Milenial. WACANA, 12(1), 65-77.

Fatihudin, D. (2015). Metode Penelitian. Sidoarjo: Zifatama Publisher.

Fitriani, M. R., \& Hidayah, N. (2016). Keefektifan Konseling Kelompok Adler untuk Meningkatkan Keterampilan Interpersonal Siswa SMP. Jurnal Kajian Bimbingan Dan Konseling, 1(1), 7-11.

Gladding, S. T., \& Gladding, C. (1991). The ABCs of Bibliotherapy for School Counselors. The School Counselor, 39(1), 7-13. Retrieved from http://www.jstor.org/stable/23901529

Hamalik, O. (2010). Psikologi Belajar dan Mengajar. Bandung: PT. Sinar Baru Algesindo.

Hasfera, D. (2018). Bibliotheraphy: Layanan bimbingan konseling di perpustakaan. Shaut AlMaktabah: Jurnal Perpustakaan, Arsip Dan Dokumentasi, 10(1), 39-62.

Hendrik, H., \& Elmansyah, T. (2018). Meningkatkan keterampilan interpersonal melalui konseling teman sebaya Sekolah Menengah Atas Negeri 1 Segedong. JBKI (Jurnal Bimbingan Konseling Indonesia), 3(1), 22-26.

Hurlock, E. B. (2012). Psikologi Perkembangan, Suatu Pendekatan Sepanjang Rentang Kehidupan. Jakarta: Penerbit Erlangga.

Hussin, A. H. M., Ibrahim, M. A. A., \& Shafie, A. A.-H. (2014). Terapi Biblio Kepulihan. Malaysia: 
Universiti Sains Islam Malaysia.

Hynes, A. M., \& Hynes-Berry, M. (1986). Bibliotherapy The Interactive Process. New York: Routledge.

Johnson, D. W. (2014). Reaching Out, Interpersonal Effectiveness and Self-Actualization, Eleventh Edition. USA: Allyn Bacon.

Kompas. (2019). Sebagian Kasus Kenakalan Remaja Dipicu Media Sosial. Retrieved from https://kompas.id/baca/nusantara/2019/12/20/sebagian-kasus-kenakalan-remaja-dipicumedia-sosial/

Kuntjara, E. (2003). Gender, bahasa, dan kekuasaan. BPK Gunung Mulia.

LN, S. Y., \& Nurihsan, A. J. (2007). Teori Kepribadian. Bandung: PT. Remaja Rosdakarya.

Noor, T. R. (2017a). Analisis Desain Fasilitas Umum Bagi Penyandang Disabilitas (Sebuah Analisis Psikologi Lingkungan). Journal An-Nafs: Kajian Penelitian Psikologi, 2(2), 187-211.

Noor, T. R. (2017b). Fungsi Sosial-Ekonomi Pasar Tradisional (Studi Tentang Pasar Karah Kec. Jambangan, Kota Surabaya). At-Tahdzib: Jurnal Studi Islam Dan Muamalah, 5(1), 77-96.

Noor, T. R. (2017c). Manajemen Pendidikan Anak melalui Program Outbound di TK Al Muslim Surabaya. SELING: Jurnal Program Studi PGRA, 3(2), 64-75.

Noor, T. R. (2017d). Upaya Guru Dalam Menanamkan Nilai Agama di KB Al Muslim Surabaya. EDUSIANA: Jurnal Manajemen Dan Pendidikan Islam, 4(1), 65-82. https://doi.org/10.30957/edusiana.v4i1.7

Noor, T. R. (2018a). Meneropong Indonesia: Sebuah Analisis Sosiologis dan Psikologis Atas Konflik Benuansa Keagamaan Di Indonesia. Journal An-Nafs: Kajian Penelitian Psikologi, 3(2), 135-150.

Noor, T. R. (2018b). Orientasi Aktivitas Dan Kelompok Keagamaan Mahasiswa. Prosiding Seminar Nasional Islam Moderat, 1, 154-163. Jombang: Unwaha.

Noor, T. R. (2019a). Komunikasi Interpersonal Remaja Yatim Di Panti Asuhan Hidayatush Shibyan Surabaya. Prosiding Seminar Nasional Prosiding Seminar Nasional \& Call Paper Psikologi Sosial 2019, 333-340. Malang: Fakultas Pendidikan Psikologi Univ. Negeri Malang.

Noor, T. R. (2019b). Pendidikan Islam Sebagai Sebuah Sistem Di Era 4.0. TA'LIM: Jurnal Studi Pendidikan Islam, 2(2), 18-36.

Noor, T. R. (2019c). Remaja dan Pemahaman Agama. Vicratina: Jurnal Pendidikan Islam, 3(2), 5470.

Noor, T. R. (2020). Alternatif Pemecahan Masalah Pada Masyarakat Multikultural. Al Iman: Jurnal Keislaman Dan Kemasyarakatan, 4(2), 204-232.

Noor, T. R., \& Astutik, E. (2019). RODA (Rotating Education Game) sebagai Media Pembelajaran untuk Menanamkan Sikap Disiplin pada Anak Usia Dini. AS-SABIQUN, 1(2), 1-16.

Novita, K. R., Sugiharto, D. Y. P., \& Anni, C. T. (2017). Meningkatkan Kemampuan Prososial Siswa Melalui Layanan Informasi dengan Teknik Bibliotherapy. Indonesian Journal of Guidance and Counseling: Theory and Application, 6(4).

Nugent, F. A. (2002). Professional counseling, An Overview. California: Brooks/ Cole Publishing 
Company.

Pardeck, J. T. (1995). Bibliotherapy: An Innovative Approach for Helping Children. Early Child Development and Care, 110(1), 83-88. https://doi.org/10.1080/0300443951100106

Puspensos. (2020). Mengatasi Kenakalan Remaja. Retrieved from http://puspensos.kemsos.go.id/mengatasi-kenakala-remaja

Rahma, A., \& Lestari, R. (2018). Interaksi Sosial pada Remaja Kecanduan Game Online. Universitas Muhammadiyah Surakarta.

Rahmat, W. (2014). Pengaruh Tipe Kepribadian dan Kualitas Persahabatan dengan Kepercayaan pada Remaja Akhir. Psikoborneo, 2(1).

Rakhmat, J. (2013). Psikologi Komunikasi. Bandung: PT. Remaja Rosdakarya.

Sari, N. (2019). Relasi Antara Orangtua Dan Anak Ditinjau dari Sudut pandang Remaja Yang Memiliki Perilaku Delikuen. Psikologi, 1(2), 110-119.

Setiawan, M. (2015). Karakteristik kriminalitas Anak dan Remaja. Bogor: Ghalia Indonesia.

Shechtman, Z. (2009). Treating Child and Adolescent Aggression Through Bibliotherapy. New York: Springer.

Syafwar, F. (2016). Merubah Konsep Diri Negatif Remaja Dengan Bibliotherapy. Ta'dib, 18(1), 26-34.

Tafsir, A. (2014). Ilmu Pendidikan Dalam Perspektif Islam. Bandung: PT. Remaja Rosdakarya.

Walgito, B. (2010). Pengantar Psikologi Umum. Yogyakarta: CV. Andi Offset.

WHO. (2020). https://www.who.int/health-topics/adolescent-health/\#tab=tab_1. Retrieved from https://www.who.int/health-topics/adolescent-health/\#tab=tab_1

\begin{tabular}{|l|l|l|l|l|}
\hline Submit & Review & Revisi & Diterima & Publis \\
\hline 28-09-2020 & 05-10-2020 sd 30-11-2020 & $30-11-2020$ & $30-11-2020$ & $27-1-2021$ \\
\hline
\end{tabular}

Triana Rosalina Noor

Sekolah Tinggi Agama Islam (STAI) An Najah Indonesia Mandiri Sidoarjo

Email : trianasuprayoga@gmail.com 